\title{
Leptospira wolffii sp. nov., isolated from a human with suspected leptospirosis in Thailand
}

\author{
Correspondence \\ Lee D. Smythe \\ Lee_smythe@health.qld.gov.au
}

\author{
Andrew T. Slack, ${ }^{1}$ Thareerat Kalambaheti, ${ }^{2}$ Meegan L. Symonds, ${ }^{1}$ \\ Michael F. Dohnt, ${ }^{1}$ Renee L. Galloway, ${ }^{3}$ Arnold G. Steigerwalt, ${ }^{3}$ \\ Wanpen Chaicumpa, ${ }^{4}$ Gaysorn Bunyaraksyotin, ${ }^{5}$ Scott Craig, ${ }_{1}$ \\ Bruce J. Harrower ${ }^{6}$ and Lee D. Smythe ${ }^{1}$
}

\author{
${ }^{1}$ WHO/FAO/OIE Collaborating Centre for Reference and Research on Leptospirosis, Western \\ Pacific Region, Communicable Diseases, Queensland Health Forensic and Scientific Services, \\ Brisbane, Australia \\ ${ }^{2}$ Faculty of Tropical Medicine, Mahidol University, Bangkok, Thailand \\ ${ }^{3}$ Bacterial Zoonoses Branch, Coordinating Center for Infectious Diseases, Centers for Disease \\ Control and Prevention, Atlanta, GA, USA \\ ${ }^{4}$ Faculty of Allied Health Sciences, Thammasart University, Rangsit Campus, Pathumthani, Thailand \\ ${ }^{5}$ Regional Medical Sciences Center, Ministry of Public Health, Trang, Thailand \\ ${ }^{6}$ Virology Department, Communicable Diseases, Queensland Health Forensic and Scientific \\ Services, Brisbane, Australia
}

\begin{abstract}
A single Leptospira strain (designated Khorat- $\mathrm{H} 2^{\top}$ ) was isolated from the urine of an adult male patient with suspected leptospirosis from the province of Nakornrachasima, Thailand. The isolate showed typical Leptospira motility and morphology under dark-field microscopy. Cells were 10$13 \mu \mathrm{m}$ long and $0.2 \mu \mathrm{m}$ in diameter, with a wavelength of $0.5 \mu \mathrm{m}$ and an amplitude of approximately $0.3 \mu \mathrm{m}$. Phenotypically, strain Khorat- $\mathrm{H} 2^{\top}$ did not grow at $13^{\circ} \mathrm{C}$ but grew at 30 and $37{ }^{\circ} \mathrm{C}$ and in the presence of 8 -azaguanine. Serological identification using the microscopic agglutination test revealed that strain Khorat- $\mathrm{H} 2^{\top}$ had no cross-reaction with any recognized Leptospira serogroups. Phylogenetic analysis of the 16S rRNA gene sequence placed the novel strain within the radiation of the genus Leptospira, with sequence similarities of $88.1-97.7 \%$ to recognized Leptospira species. DNA-DNA hybridization against the type strains of the three most closely related Leptospira species was used to confirm the results of the 16S rRNA sequence analysis. The $\mathrm{G}+\mathrm{C}$ content of strain Khorat $-\mathrm{H} 2^{\top}$ was $41.8 \mathrm{~mol} \%$. On the basis of phenotypic, serological and phylogenetic data, strain Khorat- $\mathrm{H} 2^{\top}$ represents a novel species of the genus Leptospira, for which the name Leptospira wolffii sp. nov. is proposed. The type strain is Khorat-H2 $2^{\top}\left(=\right.$ WHO LT1686 ${ }^{\top}=$ KIT Khorat-H2 $\left.{ }^{\top}\right)$.
\end{abstract}

Leptospirosis is the zoonotic disease caused by members of the genus Leptospira, which are helical spirochaetes that metabolize long-chain fatty acids. Leptospirosis is distributed worldwide (WHO, 1999) and is considered to be an emerging disease (Bharti et al., 2003; Levett, 2001). The disease is transmitted by direct contact with infected animal urine or body fluids or by indirect contact with contaminated water or soil (Levett, 2001).

\footnotetext{
Abbreviations: CAAT, cross-agglutinin absorption test; MAT, microscopic agglutination test.

The GenBank/EMBL/DDBJ accession number for the 16S rRNA gene sequence of strain Khorat- $\mathrm{H}^{\top}{ }^{\top}$ is EF025496.
}

There are currently 17 Leptospira species as delineated by DNA-DNA hybridization (Brenner et al., 1999; Levett et al., 2006; Perolat et al., 1998; Yasuda et al., 1987). Phylogenetic analysis of the 17 species using the $16 \mathrm{~S}$ rRNA gene has resulted in the broad classification of the species into pathogenic, saprophytic and intermediates (Perolat et al., 1998). Leptospira species are also divided serologically through the cross-reaction of cell antigens using the crossagglutinin absorption test (CAAT); over 200 serovars have been described for the genus (Levett, 2001).

In this paper, we report on the characterization of a novel species of Leptospira using serology, phenotypic studies and molecular studies including 16S rRNA gene sequence analysis, DNA-DNA hybridization and $\mathrm{G}+\mathrm{C}$ content. 
Strain Khorat $-\mathrm{H} 2^{\mathrm{T}}$ was isolated from the urine of an adult male patient with suspected leptospirosis from the Thai province of Nakornrachasima (Khorat) by researchers at the Faculty of Tropical Medicine, Mahidol University (Bangkok, Thailand). The isolate was forwarded to the WHO/FAO/OIE Collaborating Centre for Reference \& Research on Leptospirosis (Brisbane, Australia) for further identification. Strain Khorat- $\mathrm{H}_{2}{ }^{\mathrm{T}}$ and all other Leptospira strains used in this study were maintained in Ellinghausen McCullough Johnson Harris (EMJH) medium (Difco) at $30{ }^{\circ} \mathrm{C}$.

Phenotypic characterization of strain Khorat- $\mathrm{H} 2^{\mathrm{T}}$ was performed by assessing growth at varying temperatures and in the presence of 8-azaguanine (Johnson \& Rogers, 1964). Duplicate aliquots of EMJH medium were inoculated with strain Khorat- $\mathrm{H}_{2}^{\mathrm{T}}$ and incubated at 13, 30 and $37{ }^{\circ} \mathrm{C}$ for 14 days. The cultures were then inspected for growth using dark-field microscopy. Growth was confirmed by subculturing into $\mathrm{EMJH}$ medium (without 8azaguanine) and incubating the subcultures at $30{ }^{\circ} \mathrm{C}$ for a further 7 days. Leptospira interrogans serovar Pomona strain Pomona, Leptospira biflexa serovar Patoc strain Patoc $1^{\mathrm{T}}$ and Leptospira inadai serovar Lyme strain $10^{\mathrm{T}}$ were used as controls in the experiments to represent pathogenic, saprophytic and intermediate species, respectively. Strain Khorat- $\mathrm{H}_{2}{ }^{\mathrm{T}}$ did not grow in $\mathrm{EMJH}$ medium at $13{ }^{\circ} \mathrm{C}$ but did grow at $30{ }^{\circ} \mathrm{C}$ and in the presence of 8 azaguanine.

Serological identification of the isolates was performed using the microscopic agglutination test (MAT) method using serovars representative of the major Leptospira serogroups (Faine et al., 1999). The Leptospira serogroups tested included Icterohaemorrhagiae, Javanica, Celledoni, Canicola, Ballum, Pyrogenes, Cynopteri, Autumnalis, Djasiman, Australis, Pomona, Grippotyphosa, Hebdomadis, Mini, Sejroe, Bataviae, Tarrasovi, Panama, Shermani and Semeranga. Strain Khorat- $\mathrm{H} 2^{\mathrm{T}}$ produced no reactions against any of the serogroups tested and therefore represents a novel serovar.

Cultures were prepared for DNA isolation by centrifugation as described previously (Slack et al., 2006) followed by genomic DNA extraction using the ChargeSwitch gDNA mini bacteria kit (Invitrogen). 16S rRNA gene amplification was performed in a final volume of $25 \mu \mathrm{l}$ containing $1 \times$ PCR buffer (NEB), $2.0 \mathrm{mM} \mathrm{MgCl} 2,200 \mu \mathrm{M}$ dNTPs, 10.0 pmol primers FD1MOD (Kotilainen et al., 1998) and 13R (Relman et al., 1992), 1 U Taq polymerase (NEB), $2 \mu \mathrm{l}$ DNA extract and double-distilled water $\left(\mathrm{ddH}_{2} \mathrm{O}\right)$ to make up the final volume. Thermal cycling was as follows: initial denaturation at $94{ }^{\circ} \mathrm{C}$ for 10 min followed by 35 cycles of $94{ }^{\circ} \mathrm{C}$ for 30 s, $55{ }^{\circ} \mathrm{C}$ for 30 s and $72{ }^{\circ} \mathrm{C}$ for 30 s, with a final extension at $72{ }^{\circ} \mathrm{C}$ for $10 \mathrm{~min}$. PCR products were confirmed by agarose gel electrophoresis $(1.5 \% \mathrm{w} / \mathrm{v})$ of $5 \mu \mathrm{l} \mathrm{PCR}$ product for $60 \mathrm{~min}$ at $80 \mathrm{~V}$. Excess primers and dNTPs were removed from the remaining PCR product $(20 \mu \mathrm{l})$ using an enzymic method. Briefly, $2.5 \mu \mathrm{l} 10 \times$
Antarctic phosphatase buffer (NEB), 10 U E. coli exonuclease I (Fermentas), $2.5 \mathrm{U}$ Antarctic phosphatase (NEB)

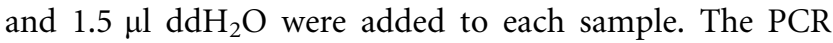
product plus enzyme mixture was incubated at $37{ }^{\circ} \mathrm{C}$ for $45 \mathrm{~min}$ followed by $85{ }^{\circ} \mathrm{C}$ for $15 \mathrm{~min}$ to inactivate the enzyme. DNA sequencing was performed using the Big Dye Terminator (BDT) sequencing kit version 3.1 (Applied Biosystems) using the original primers and internal primers 515F, 91e, 11e, 16s1RRB, 907R and 342R (Lane, 1991; Relman et al., 1990, 1992; Wilbrink et al., 1998) with the following modifications. Each $20 \mu \mathrm{l}$ reaction contained a $1: 16$ dilution of BDT mix $(0.5 \mu \mathrm{l}), 3.75 \mu \mathrm{l} 5 \times$ dilution buffer, 3.2 pmol primer, 5-10 ng DNA and $\mathrm{ddH}_{2} \mathrm{O}$ to make up the final volume. Cycle sequencing was performed using 30 cycles of $95{ }^{\circ} \mathrm{C}$ for $10 \mathrm{~s}, 50{ }^{\circ} \mathrm{C}$ for $10 \mathrm{~s}$ and $60{ }^{\circ} \mathrm{C}$ for $4 \mathrm{~min}$. The cycle-sequencing products were purified using sodium acetate/alcohol precipitation according to the manufacturer's instructions (Applied Biosystems). The purified products were forwarded to the Griffith University DNA sequencing facility (GUDSF; Brisbane, Australia) for capillary electrophoresis using the ABI 3130xl instrument. Sequences were assembled and trimmed to a minimum of two contiguous sequences using Vector NTI software (Invitrogen). Sequences from strain Khorat- $\mathrm{H} 2^{\mathrm{T}}$ and representative sequences from the genus Leptospira were aligned with CLUSTAL $\mathrm{W}$ (Thompson et al., 1994). Using MEGA4 (Tamura et al., 2007), distances of aligned sequences were estimated by the method of Jukes \& Cantor (1969) and bootstrapped 1000 times and the tree topology was determined by the neighbour-joining method (Fig. 1). 16S rRNA gene sequence similarity between strain Khorat- $\mathrm{H} 2^{\mathrm{T}}$ and strains of the 17 previously described Leptospira species was $88.1-97.7 \%$. The type strains of Leptospira broomii (97.7\%), Leptospira fainei (97.7\%) and L. inadai (97.4\%) showed the highest 16S rRNA gene sequence similarity to strain Khorat- $\mathrm{H} 2^{\mathrm{T}}$. Phylogenetic analysis showed that strain Khorat- $\mathrm{H} 2^{\mathrm{T}}$ was placed within the radiation of the genus Leptospira and formed a unique lineage within the clade formed by the intermediates/potentially pathogenic Leptospira species.

DNA was isolated for DNA-DNA hybridization and G + C content analysis from strain Khorat- $\mathrm{H} 2^{\mathrm{T}}$, L. broomii $5399^{\mathrm{T}}$, L. fainei serovar Hurstbridge strain BUT $6^{\mathrm{T}}$ and L. inadai serovar Lyme strain $10^{\mathrm{T}}$ as described by Brenner et al. (1982). The isolated DNA was labelled with $\left[{ }^{32} \mathrm{P}\right] \mathrm{dCTP}$ and DNA relatedness and divergence studies were performed using the hydroxyapatite method at the optimal reassociation temperature of $55{ }^{\circ} \mathrm{C}$ (Brenner et al., 1982). Strain Khorat- $\mathrm{H} 2^{\mathrm{T}}$ showed no significant relatedness to $L$. fainei BUT $6^{\mathrm{T}}$ (relative binding ratio $19 \%$, divergence $23.5 \%$ ), $L$. inadai $10^{\mathrm{T}}$ (relative binding ratio $22 \%$, divergence $23.0 \%$ ) or L. broomii $5399^{\mathrm{T}}$ (relative binding ratio $18 \%$, divergence $22.5 \%)$. The $\mathrm{G}+\mathrm{C}$ content was determined by the thermal denaturation method as described by Mandel et al. (1970). The $\mathrm{G}+\mathrm{C}$ content of strain Khorat- $\mathrm{H} 2^{\mathrm{T}}$ was $41.8 \mathrm{~mol} \%$, which is within the range of $33-43 \mathrm{~mol} \%$ reported for the genus Leptospira (Yasuda et al., 1987). 


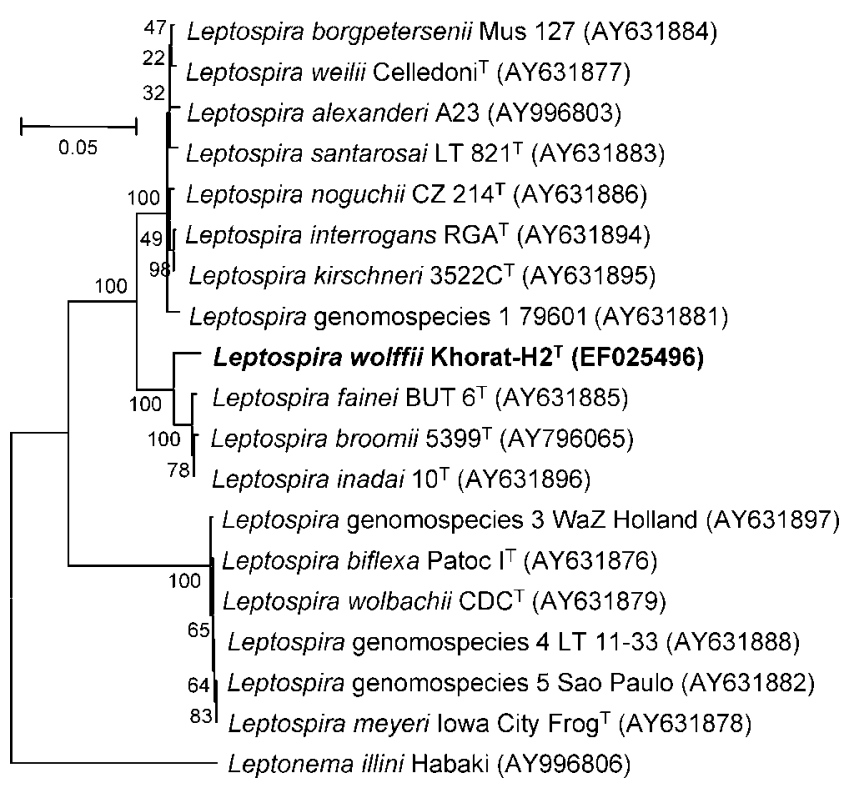

Fig. 1. $16 \mathrm{~S}$ rRNA gene sequence-based phylogeny of strain Khorat- $\mathrm{H}_{2}^{\top}$ and representative Leptospira species. The dendrogram was reconstructed from distance matrices using the neighbour-joining method, using Leptonema illini strain Habaki as an outgroup. Bootstrap values are indicated as percentages of 1000 resamplings. Bar, 0.05 inferred substitutions per nucleotide position.

Although strain Khorat- $\mathrm{H} 2^{\mathrm{T}}$ shares a high level of $16 \mathrm{~S}$ rRNA gene sequence similarity with three previously recognized Leptospira species ( $L$. inadai, $L$. fainei and $L$. broomii), it forms its own distinct phylogenetic lineage. This novel lineage is supported by the DNA-DNA hybridization investigations, which showed significant divergence from $L$. inadai, $L$. fainei and $L$. broomii. The limited phenotypic characterization of Leptospira species can be offset by the fact that strain Khorat- $\mathrm{H} 2^{\mathrm{T}}$ was found to be serologically unique and represented a novel serovar. This research provides sufficient evidence in the form of molecular and serological taxonomic characterization to justify the inclusion of strain Khorat $\mathrm{H} 2^{\mathrm{T}}$ within a novel species of the genus Leptospira, for which the name Leptospira wolffii sp. nov. is proposed. However, this research does not show whether this strain represents a true human pathogen, as the isolation was not supported at the time by other investigations such as MAT or PCR. The novel species and serovar designation of strain Khorat- $\mathrm{H}_{2}{ }^{\mathrm{T}}$ as Leptospira wolffii serovar Khorat has been ratified by the International Committee on Systematics of Prokaryotes Subcommittee on the taxonomy of Leptospiraceae.

\section{Description of Leptospira wolffii sp. nov.}

Leptospira wolffii (wolf'fi.i. N.L. gen. masc. n. wolffii of/ from Wolff, named after Dr Jan Willem Wolff, a Dutch bacteriologist who made significant contributions to the study of Leptospira).
Shows typical Leptospira motility and morphology under dark-field microscopy. Cells are $10-13 \mu \mathrm{m}$ long and $0.2 \mu \mathrm{m}$ in diameter, with a wavelength of $0.5 \mu \mathrm{m}$ and an amplitude of approximately $0.3 \mu \mathrm{m}$. Does not grow at $13{ }^{\circ} \mathrm{C}$ but grows at 30 and $37{ }^{\circ} \mathrm{C}$ and in the presence of 8 azaguanine. Serological identification using MAT reveals that the type strain has no cross-reaction with any recognized Leptospira serogroups. Phylogenetic analysis of the $16 \mathrm{~S}$ rRNA gene sequence places the type strain within the radiation of the genus Leptospira, as confirmed by DNA-DNA hybridization. The DNA G $+\mathrm{C}$ content of the type strain is $41.8 \mathrm{~mol} \%$.

The type strain, Khorat $-\mathrm{H} 2^{\mathrm{T}}\left(=\mathrm{WHO}\right.$ LT1686 ${ }^{\mathrm{T}}=\mathrm{KIT}$ Khorat- $\mathrm{H} 2^{\mathrm{T}}$ ), was isolated from the urine of a human patient with suspected leptospirosis in Nakornrachasima, Thailand. This strain is also the reference strain of Leptospira wolffii serovar Khorat.

\section{Acknowledgements}

The authors would like to thank the Thailand Tropical Diseases Research Programme (T-2) (grant ID 02-2-LEP-02-027), National Center for Genetic Engineering and Biotechnology, for their financial support of this project. We also thank Hans Trüper for his kind advice regarding the etymology of the species name.

\section{References}

Bharti, A. R., Nally, J. E., Ricaldi, J. N., Matthias, M. A., Diaz, M. M., Lovett, M. A., Levett, P. N., Gilman, R. H., Willig, M. R. \& other authors (2003). Leptospirosis: a zoonotic disease of global importance. Lancet Infect Dis 3, 757-771.

Brenner, D. J., McWhorter, A. C., Knutson, J. K. \& Steigerwalt, A. G. (1982). Escherichia vulneris: a new species of Enterobacteriaceae associated with human wounds. J Clin Microbiol 15, 1133-1140.

Brenner, D. J., Kaufmann, A. F., Sulzer, K. R., Steigerwalt, A. G., Rogers, F. C. \& Weyant, R. S. (1999). Further determination of DNA relatedness between serogroups and serovars in the family Leptospiraceae with a proposal for Leptospira alexanderi sp. nov. and four new Leptospira genomospecies. Int J Syst Bacteriol 49, 839-858.

Faine, S., Adler, B. \& Bolin, C. (editors) (1999). Leptospira and Leptospirosis, 2nd edn. Armadale, Victoria: MediSci.

Johnson, R. C. \& Rogers, P. (1964). Differentiation of pathogenic and saprophytic leptospires with 8-azaguanine. J Bacteriol 88, 1618-1623.

Jukes, T. H. \& Cantor, C. R. (1969). Evolution of protein molecules. In Mammalian Protein Metabolism, vol. 3, pp. 21-132. Edited by H. N. Munro. New York: Academic Press.

Kotilainen, P., Jalava, J., Meurman, O., Lehtonen, O. P., Rintala, E., Seppala, O. P., Eerola, E. \& Nikkari, S. (1998). Diagnosis of meningococcal meningitis by broad-range bacterial PCR with cerebrospinal fluid. J Clin Microbiol 36, 2205-2209.

Lane, D. J. (1991). 16S/23S rRNA sequencing. In Nucleic Acid Techniques in Bacterial Systematics, pp. 115-175. Edited by E. Stackebrandt \& M. Goodfellow. Chichester: Wiley.

Levett, P. N. (2001). Leptospirosis. Clin Microbiol Rev 14, 296-326.

Levett, P. N., Morey, R. E., Galloway, R. L. \& Steigerwalt, A. G. (2006). Leptospira broomii sp. nov., isolated from humans with leptospirosis. Int J Syst Evol Microbiol 56, 671-673. 
Mandel, M., Igambi, L., Bergendahl, J., Dodson, M. L., Jr \& Scheltgen, E. (1970). Correlation of melting temperature and cesium chloride buoyant density of bacterial deoxyribonucleic acid. $J$ Bacteriol 101, 333-338.

Perolat, P., Chappel, R. J., Adler, B., Baranton, G., Bulach, D. M., Billinghurst, M. L., Letocart, M., Merien, F. \& Serrano, M. S. (1998). Leptospira fainei sp. nov., isolated from pigs in Australia. Int J Syst Bacteriol 48, 851-858.

Relman, D. A., Loutit, J. S., Schmidt, T. M., Falkow, S. \& Tompkins, L. S. (1990). The agent of bacillary angiomatosis. An approach to the identification of uncultured pathogens. N Engl J Med 323, 1573-1580.

Relman, D. A., Schmidt, T. M., MacDermott, R. P. \& Falkow, S. (1992). Identification of the uncultured bacillus of Whipple's disease. $N$ Engl J Med 327, 293-301.

Slack, A. T., Symonds, M. L., Dohnt, M. F. \& Smythe, L. D. (2006). Identification of pathogenic Leptospira species by conventional or real-time PCR and sequencing of the DNA gyrase subunit B encoding gene. BMC Microbiol 6, 95.
Tamura, K., Dudley, J., Nei, M. \& Kumar, S. (2007). MEGA4: molecular evolutionary genetics analysis (MEGA) software version 4.0. Mol Biol Evol 24, 1596-1599.

Thompson, J. D., Higgins, D. G. \& Gibson, T. J. (1994). CLUSTAL W: improving the sensitivity of progressive multiple sequence alignment through sequence weighting, position-specific gap penalties and weight matrix choice. Nucleic Acids Res 22, 4673-4680.

WHO (1999). Leptospirosis worldwide, 1999. Wkly Epidemiol Rec 74, 237-242.

Wilbrink, B., van der Heijden, I. M., Schouls, L. M., van Embden, J. D., Hazes, J. M., Breedveld, F. C. \& Tak, P. P. (1998). Detection of bacterial DNA in joint samples from patients with undifferentiated arthritis and reactive arthritis, using polymerase chain reaction with universal $16 \mathrm{~S}$ ribosomal RNA primers. Arthritis Rheum 41, 535-543.

Yasuda, P. H., Steigerwalt, A. G., Sulzer, C. R., Kaufmann, A. F., Rogers, F. C. \& Brenner, D. J. (1987). Deoxyribonucleic acid relatedness between serogroups and serovars in the family Leptospiraceae with proposals for seven new Leptospira species. Int $J$ Syst Bacteriol 37, 407-415. 